\title{
A survey of weeding practices in New Zealand academic libraries
}

\author{
By Angus Johnston
}

Submitted to the School of Information Management, Victoria University of Wellington, in partial fulfilment of the requirements for the degree of Master of Information Studies.

July 2011 


\section{Table of Contents}

\section{Introduction}

Problem statement....4

\section{Literature review....4}

Weeding guidelines

Reasons for weeding

Weeding theory

Criteria used in weeding projects

Use of literature in weeding projects

Effect of weeding on circulation

\section{Methodology....7}

\section{Research design...7}

Research question

Method

Population

Sample

Delimitations

Ethics

Results....9

Reasons for weeding

Frequency of weeding

Factors discouraging weeding

Weeding criteria used

Use of literature in weeding projects

Effect of weeding on circulation

Recommendations for improving the weeding process

Discussion...14

Conclusion...14

Suggestions for future research....15

References....16

Bibliography...19

Appendix A: Survey questions

Appendix B: Information sheet 


\section{Introduction}

Weeding is the removal and disposal of materials from a library's collection that meet criteria set out in the collection development policy. Weeding the print collection of an academic library should be viewed as a means of continuously improving the quality of the collection, reflecting changes in the university's academic curriculum and meeting patrons' research needs (Dubicki, 2008). Weeding is often neglected however because of time constraints, a desire to maintain the size of a collection, and the belief that a book may be needed some time in the future.

Most libraries face space restraints. Collections continue to grow while shelf space and storage space is limited, making regular weeding an essential part of collection management. As an example, the library at Victoria University of Wellington receives 30,000 new items each year. If the collection is not weeded regularly, a new floor needs to be built every five or six years.

Neglecting weeding puts pressure on space for users. At one university library, nearly a whole floor is occupied by shelving for serials, which are rarely browsed. On the same floor are study areas and computers, which are in full use students the majority of the time. With growing numbers of students, weeding these serials and removing shelving would provide well-needed extra study space.

Weeding has the benefit of increasing reader satisfaction. When older and unused books are removed, the shelves appear more attractive to users and it is easier for them to find newer or more popular items (Lancaster, 1988). Weeding also benefits staff in saving time in shelving and re-shelving. In the process of weeding staff gain a greater knowledge and awareness of the contents of a collection (Slote, 1997).

Many people consider books to be valuable records of human heritage and therefore almost sacred (Slote, 1997). Proposals to weed can stir up strong emotions in students and faculty. As an example the Fisher Library at Sydney University has controversial plans to remove 500,000 books and journals, reducing the main stack by almost half. This will make way for increased study space, a coffee cart and better access for students with disabilities. Staff and students have vigorously opposed the move to reduce the collection, even borrowing books en masse in protest to prevent volumes being removed from the library's shelves (Narushima, 2011).

Some of the objections to weeding are based on misconceptions. One such misconception is that scholarly work depends on being able to browse large collections. However significant portions of academic library collections cannot be browsed because books are lost, missing or stolen. Furthermore when a book is sent off site the book does not become forever unavailable or undiscoverable. Thanks to online search tools, items that go offsite in the digital age are actually more discoverable than when they were sitting on the shelf (Barclay, 2006).

While an effective weeding programme can improve cost-effectiveness by moving little used materials to less expensive storage areas, weeding itself has costs. There 
are costs in identifying which materials to discard or relocate, in altering catalogue records, and when retrieving materials from remote storage when requested by patrons (Lancaster, 1988).

Despite these issues, there has never been a better time for weeding according to Lugg and Fischer (2008). More content is accessible digitally. The infrastructure for resource sharing such as "borrow direct" and inter-library loan services has improved. Nowadays withdrawn content is easier to access or replace if needed, for example Google book search has one million digitised full-text titles.

\section{Problem statement}

Academic libraries today face a variety of pressures including rapidly growing collections, financial pressures, lack of space and the high cost of storing books on open stacks (Slote, 1997). Therefore it is essential for libraries to have a systemic approach to weeding to avoid overcrowding of their collections.

Surveys about how and why libraries weed are rare. Goldstein's (1981) study of the weeding policies and practices of a group of medical libraries surveyed the reasons for weeding, criteria used and how items were disposed of. Another quantitative study by Dilevko and Gottlieb (2003) surveyed public libraries, looking at various factors including why weeding is discouraged, the effects of weeding on staff and personal beliefs about deselecting. There have been no recent studies of weeding in academic libraries.

A survey of weeding practices in New Zealand university libraries would provide qualitative insights into issues such as what discourages libraries from weeding and how librarians think that their weeding processes could be improved. The aim of this research is to discover if there is a gap between current weeding practice and best practice, as identified in the literature.

\section{Literature review}

\section{Weeding guidelines}

The literature contains several narrations of successful weeding projects at academic libraries that include valuable guidelines. For example Handis (2007) provides sensible weeding suggestions such as removing anything with mould or a heavy coat of dust and using Integrated Library System (ILS) reports to identify items that have not circulated in years. Dubicki (2008) advises libraries to have a clear project plan, collaborate closely with faculty and have multiple reviews of books selected for withdrawal. Metz and Gray (2005) advise that advance notice, clear criteria, flexibility in weeding decisions and candid response to criticism will result in fewer objections from faculty. 


\section{Reasons for weeding}

In the case studies, weeding projects were commonly carried out because of space restraints. For example, at a small academic library there had been a lack of weeding for several years and now there was a "space crunch" (Handis, 2007). At a community college library the stacks were at $100 \%$ capacity and the withdrawal rate had been less than $1 \%$ per year for the last thirty years (Burgett, 2006). Other reasons for weeding included having outdated materials (Dubicki, 2008) and materials that had become increasingly irrelevant to current courses (Hann, 2002).

\section{Weeding theory}

In his seminal work "Weeding Library Collections," Slote (1997) describes a number of different general approaches to weeding. These include subjective weeding, curriculum related weeding, weeding according to publication date, shelf time period, mathematical approaches and combined criteria.

Slote (1997) argues that weeding criteria based on subjective criteria is riddled with difficulties. Librarians can never really know the content of the collections and their patrons' needs. Lancaster (1988) agrees, arguing that weeding, like acquisitions, can be carried out effectively only if based on an objective evaluation. He advocates using "obsolescence" (the decline in use of library materials as they age) as a method for weeding.

Slote (1997) contends that shelf time period is the preferred criteria for weeding a collection. This technique measures the time a book remains on the shelf between circulations. Using a cut-off date determines the library's core collection - items that circulate regularly and should be retained. Non-core books, which rarely or never circulate, are candidates for weeding.

The problem with the shelf time method is that it trades relative simplicity for greater accuracy in weeding decisions (Bartley, 1999). The different circulation patterns according to subject area show that a library should be wary of trying to satisfy a certain percentage of users by weeding all books uncirculated since an arbitrary cutoff date (Basart, 1980). Bartley (1999) argues that weeding methods should combine the judgment of experienced librarians with quantitative criteria, such as circulation data. Fabbi (2003) agrees, believing that there is a happy medium between objective and subjective weeding criteria.

The CREW (Continuous Review, Evaluation and Weeding) method provides a model for integrating weeding into the entire selection and acquisitions process (Dilevko and Gottlieb, 2003). One guiding principle from this method is that of MUSTY:

Misleading, Ugly, Superseded, Trivial, Your collection has no use for. All materials which meet these criteria are candidates for withdrawal. This is a simple method using an analytic approach that can be defended from all perspectives (Rogers, 2007).

The MUSTY formula combines objective and subjective criteria. For example the formula "8/3/MUSTY" could be read: consider a book in this category when its latest copyright date is more than eight years ago; and/or when its last circulation was more 
than three years ago; and/or when it possesses one or more of the MUSTY factors. The formula varies depending on the subject area being reviewed. For example economics has a suggested latest copyright date of three years, while for philosophy it is fifteen years (Larson, 2008).

The difference between CREW and the shelf time method is that CREW takes into account that one size does not fit all and that different subject areas may have different acceptable time periods since the last circulation. This is particularly true in research collections (Emma Shepherd, personal communication, July 12, 2011).

There are less formal approaches to weeding based on personal preferences. For instance Carey (1990) advocates survival weeding. "When going down an aisle in search of a history of Korea, pull those two tattered books on China. It only takes a second." Another simple and less formal approach is the "dust test." If there is a thick coat of dust on a book, it will not have been touched in years and should be withdrawn (Handis, 2007).

Rogers (2007) concluded that a library is best suited having a continuing, systematic program utilizing a variety of approaches which keep the collection current and managed without undue stress.

\section{Criteria used in weeding projects}

According to Slote (1997), most weeding is conducted based on a combination of objective and subjective criteria, perhaps to allay the emotional conflicts of those weeding. For example, a university music library combined objective data drawn from each book, statistics to do with use, and qualitative data such as the importance and relevance of each book (Basart, 1980). More recently Fabbi (2003) used a Digital Library Assistant to identify items for weeding, such as those with low circulation use. Once the books were taken off the shelf, they were assessed by a librarian.

Rogers (2007) came to the conclusion that there are many different approaches to weeding and not all of them fit every circumstance. For example, as one library was faced with a tight time frame, it used readily available data about items to be weeded provided by the ILS, as well as more subjective criteria such as appropriateness to the collection (Crosetto abd Duhon, 2008). The library at the Manukau Institute of Technology (MIT) had only a limited amount of circulation data available for its weeding project, so items were assessed for withdrawal based on their publication date (Hann, 2001).

\section{Use of literature in weeding projects}

Many libraries carried out a literature review before beginning a weeding project. MIT did a literature search on the weeding and withdrawal process (Hann, 2001). A music library used various studies to help it compile a list of items to be considered as weeding factors (Basart, 1980). Another library looked at relevant literature such as CREW: A weeding manual for modern libraries (Larson, 2008) and Weeding Library 
Collections (Slote, 1997), before assessing and weeding a foreign language collection (Williams and Halvonik, 2004).

\section{Effects of weeding on circulation}

Weeding should lead to improved circulation (Slote, 1997). The circulation for the foreign language collection increased at one university library after a weeding project (Williams and Halvonik, 2004). Nikkel and Belway (2009) reported that a weeding project increased interest in an academic collection, both on and off campus. However after a study of circulation patterns at another university library, Banks (2002) concluded that weeding does not improve circulation because of the paradigm shift away from book usage towards the Internet and online database use.

\section{Methodology}

The researcher approached the study with a social constructivist worldview. Social constructivists believe that individuals develop subjective meanings of their experiences. These meanings are varied, leading researchers to look for complexity of views rather than narrowing meanings into a few categories or ideas (Cresswell, 2009). Social constructivism lends itself to a qualitative methodology, where using open-ended questions allow the respondents to construct the meaning of a situation.

A qualitative methodology was used to gain an in-depth understanding of librarians' behaviour in relation to weeding. The advantage of qualitative methods is that using open-ended questions gives people the opportunity to respond in their own words, rather than forcing them to choose from fixed responses, as quantitative methods do (Mack, Woodsong, MacQueen, Guest, and Namey, 2005). The disadvantage of using qualitative data is that it cannot be mathematically analysed in the same comprehensive way as quantitative results, so it can only give a guide to general trends. It is much more open to personal opinion and judgement and provides observations rather than results (Shuttleworth, 2008).

\section{Research Design}

\section{Research question}

What is the gap between current weeding practice in New Zealand academic libraries and best practice, as identified in the literature? 


\section{Method}

Initially the researcher considered using a self-completion questionnaire, administered by email. This method has the advantage of being cheap and quick to administer. It is convenient for respondents as they can complete it when they want and at the speed that they want to go. A major disadvantage is that the researcher is limited to using mainly closed questions, which means that they cannot probe the respondent to elaborate on answers or collect additional data (Bryman, 2008). There is also no one to help the respondent answer questions that they find ambiguous or confusing.

For these reasons the researcher decided to use telephone surveys. One drawback with telephone interviews is that that the interviewer cannot be seen and the visual cues that are important in establishing a rapport with the respondent are lost (Arksey and Knight, 1999). However face-to-face interviewing was not a viable method as the respondents were scattered over a wide geographical area. Interviewing as a whole is useful when participants cannot be directly observed, and it allows them to provide historical information (Cresswell, 2009).

The interviews were semi-structured. This is a less formal approach to asking questions than that employed in a structured interview. Interviewers can vary the sequence of questions, follow up ideas, probe responses and ask for clarification or further elaboration. For their part, informants can answer the questions in terms of what they see as important (Arksey and Knight, 1999).

A senior library manager from each university library was contacted by email to ask if they would like to participate in the survey. Alternatively they suggested another librarian who would be suitable. An introductory email was sent to the respondent informing them about the nature of the survey. After gaining their informed consent, a time was organised for a telephone interview. The interviews took roughly twenty minutes. Nine respondents took part, including two liaison librarians from the same university. The respondents included staff from general libraries and divisional libraries. One library manager declined to be interviewed over the phone and answered the survey questions by email instead.

\section{Population}

The research population was subject (or liaison) librarians and collection managers or senior managers from each of New Zealand's university libraries. As well as developing the collection, subject librarians are responsible for weeding the collection, usually working in conjunction with teaching faculty from their subject area and library management.

\section{Sample}

Being only a small-scale social survey, purposive sampling was used. This is a nonprobability sampling method in which the researcher obtains a sample that appears to 
them to be representative of the population. The sample included a librarian chosen from each of New Zealand's eight university libraries.

\section{Delimitations}

The survey investigated weeding practices for monographs only. It did not include reference material or serials.

\section{Ethics}

Approval was received from Victoria University of Wellington's Human Ethics Committee. The research data is confidential but the participants in the survey were not anonymous - the researcher knew the names of the subjects that were interviewed. Care was taken to ensure it was not made obvious which university was being referred to when discussing weeding practices in the report.

\section{Results}

\section{Reasons for weeding}

Lack of space is a common reason for weeding. Some libraries reported that they have done "crisis weeding." For example, one library needed to weed a certain area of the collection in order to get books off the floor. On the other hand a smaller library did not have a space problem and has enough growth for the next five to seven years. Another library also had sufficient shelf space, although it had recently reduced its collection significantly as it was moving into a new building where it had to share space with other university services.

Two of the libraries surveyed have steady state collections. This means that material held in the open collections needs to be deselected so that they are maintained at their current size. This is to relieve pressure on the existing building capacity and on the pressure for new buildings. While the collection continues to grow, material weeded from the open collections is relegated to storage facilities

Having material that is not longer relevant to courses being offered by the university is another good reason to weed. At one library a librarian said that they had some materials on beauty therapy that she wanted to donate to another institution that was teaching this subject. This would also free up some badly needed shelf space. However another librarian pointed out that even if something is not taught now, they need to consider whether it might be taught in the future.

Having obsolete materials on the shelves is another common reason. For example, at a health sciences library a liaison librarian was prompted to withdraw some pharmacology textbooks because a lecturer complained that they were outdated and therefore dangerous. 
The recent earthquake and continuing aftershocks in Christchurch have focussed one library more on weeding. It reviewed what immediate weeding could be done in order to reduce the height of its stacks, and further provide space to reshelve collections that are not well represented online, such as New Zealand journals.

\section{Frequency of weeding}

All libraries do on-going weeding as opportunities arise. This could include withdrawing an old edition of a textbook when a new edition is purchased and withdrawing an item from the collection that is damaged beyond repair.

Most libraries have systematic weeding projects running constantly, either librarywide or subject based. A number of librarians said that regular weeding is particularly important in subject areas that need to be regularly reviewed, such as computing, law and nursing. Most librarians however feel that they do not weed regularly enough.

In some cases the collection development policy (CDP) provides weeding targets. At one library the CDP specifies that $10 \%$ of the collection should be evaluated each year, and at least $3 \%$ of this amount should be discarded. This is the ideal though as one librarian said. Another library's CDP recommended that book collections be reviewed for weeding on a three-year cycle. The collections manager said this was a rough guide only and they were heading towards a five-year plan. Other librarians said that they do not have weeding targets unless driven by space.

\section{Factors discouraging weeding}

Having enough time to weed is an issue for most libraries. Several staff are involved in any weeding exercise and they contribute a range of skills from physical handling, to catalogue checking, to subject knowledge and consulting with academics. Finding time to apply the necessary rigor to the process can be a challenge.

One librarian said that while she would like to have a concerted weeding programme where the whole collection was weeded every 5 years, it is not realistic from a staffing perspective. Another problem is that "collections are not on people's desks." Unless there is a problem weeding tends to be a low priority.

Most librarians agreed that weeding is a politically charged process. One manager commented that academics as a rule dislike weeding as they think that libraries should retain everything. By throwing books away faculty believe that the library is abandoning one of its key roles, which is acquisitioning, conservation and preservation. This attitude is particularly true in humanities, as faculty and staff tend to be heavy library users and put a lot of store on browsing. Subjects such as architecture, graphic design and art history rely heavily on graphics so retaining print materials is important to them. On the other hand science and commerce faculty are far more in favour of deselection of monographs and replacing them with e-books, or not at all. 
Weeding brings out the protective instincts in lecturers according to one liaison librarian, so you need to remove books very cautiously. If an opinion is needed about whether to withdraw an item, he said it is wiser to ask a lecturer with knowledge of the subject but not necessarily someone who is teaching it.

Faculty are nervous about weeding at one divisional library as mistakes have been made in the past. A librarian recalled an incident in which staff members who were not familiar with the subject accidentally weeded key titles. To ensure that this does not happen again, certain items are tagged with a "do not weed" status on the catalogue. Lecturers however have long memories.

One library suffered some bad publicity when doing a large weeding project some years ago. Their weeding methodology was heavily criticised in the press. Since then they have consulted heavily and a librarian stressed that you should never take a "one size fits all approach" to weeding.

There is a reluctance of librarians to throw away an item that someone might need. However they need to consider the likely potential use of old material for research and make a call. It is not feasible to keep the last copy of every textbook. One librarian said that in the past if they were not sure, the University Librarian advised them to relegate the items to storage to avoid "putting our necks on the line."

One library was considering deselecting a large amount of religious studies material because it was no longer being taught. However the material included a number of seminal texts, and as a university library of any standing, it would be expected to hold them. As one librarian commented, this leads to a conundrum: while all this material should be on the shelf, there is not enough space for it.

Librarians need to be careful when deselecting material of a historical nature. Often they will consult faculty to decide if it has historical value or not. A health sciences librarian said that they check the Te Puna database to see who else in the country owns the book that is being reviewed. If they are the only library that holds a copy then they must retain it.

A liaison librarian said that she had been told not to weed by senior library management. She believed that this was because they lacked confidence in her ability to make good weeding decisions. However she knows the collection very well and always asks for a second opinion from her colleagues when withdrawing items.

Another factor that discourages weeding is collaborative storage obligations arising from agreements with other libraries. This means that libraries will retain some items that would otherwise be discarded.

\section{Weeding criteria used}

The survey found that, not surprisingly, libraries use a mixture of objective and subjective weeding criteria. At an engineering library, weeding criteria is a combination of looking at circulation statistics and the condition of books. 
Depending on the subject area, any books older than twenty years or used less than five times are weeded. Then librarians assess the condition of the books on the shelves. Any books that are quite scruffy are weeded, as patrons tend to ignore them, unless it is considered that they might be useful.

A health sciences librarian said that there are three main weeding criteria that are pertinent to the collection: condition, past use, and how core it is to a particular course. While past use gives an indication of how often the book is borrowed, it does not show how core it is. For example at post graduate level there may only be one student using the book, while at undergraduate level there could be hundreds of students using it, so there will be a vast discrepancy in how much each book circulates. If the condition of a book is scruffy then this probably means it has had heavy use, which means it should be retained. If it is looking brand new, then that is an indication that it has had little use, however this needs to be tied in with the date of acquisition.

Another health sciences librarian said that publication date was used as the main criteria on a major weeding project in the early 1990s. Every book that was published before 1980 was taken off the shelf. Staff then decided whether items would be withdrawn. They asked the lecturers to review items that they had doubts about, however faculty never came and in the end the books were put in a skip. Unfortunately mistakes were made and faculty were upset that some valuable materials were lost.

Most libraries find that superseded editions are easy candidates for withdrawal. One librarian remarked however that his library has twenty-year-old human anatomy books, and although these items are battered and worn, they still circulate. These textbooks are taking up valuable space on the shelves, but they cannot be weeded as they are still useful to students.

For one library, assessment (a term they use instead of weeding) goes hand in hand with selection. They run usage reports every six months and use them to make purchasing and weeding decisions. If material is being heavily used then they check what condition it is in, and buy more copies if necessary.

One library's guidelines advise that generally if a book has not been used in ten years then staff should consider removing it from open shelves, but relegation to a storage facility is the preferred option rather than disposal. The weeding policy at another institution advises withdrawing items with fewer than three charges over the previous five years, and weeding duplicates where each copy has been borrowed on average less than once a year over the past five years.

Most university libraries have either on site or offsite storage, or both. Regular assessment of storage material is important because space is limited and the service can be costly. Some libraries include criteria for weeding monographs from storage in their CDP. One library has been reviewing their closed access stack collection to ensure that what they are retaining is worthy of retention. 


\section{Use of literature in weeding projects}

Only some respondents said that they use the literature. One remarked that she keeps an eye on collection development literature and has "alerts" set up for the Scopus and Web of Science databases. When setting off on a major project she might refer back to the literature.

Another librarian was aware of Slote's (1997) work from her MLIS studies but commented that it depends on what will work in practice for the collection. She communicates informally with people in Internet chat groups about collection management issues.

\section{Effect of weeding on circulation}

None of the respondents thought that weeding increased circulation at their library. One said that she was aware from the literature that libraries have claimed that, but she had never done an empirical assessment herself. One library's collections had been moved around a lot during building renovations so it had been hard to study user behaviour.

\section{Recommendations for improving the weeding process}

More than one librarian noted that space is the wrong reason to be drive weeding. Items should be deselected because they are no longer suitable to remain on the shelves. A liaison librarian said that the problem with weeding to make space is that the same process needs to be repeated time and time again. As a result material is deselected that was previously judged valuable enough to keep when there was space for it.

Because of the dire shortage of space in her library, a liaison librarian for health sciences said that weeding should be done continuously throughout the year. This could be managed in small batches of about twenty items a week. This would require working closely with the cataloguing team to ensure records for deselected items were updated promptly. She would like weeding and selecting treated as a more holistic process.

A collections manager said that her library needs a more concerted approach to weeding. The campus libraries need to get themselves into sync, so that if a particular subject area is being weeded, it is done at the same time by each campus. If one campus library is deselecting a certain edition of a textbook, then all libraries should be doing the same. This will ensure that the collection remains as consistent as possible across all campus libraries.

One library is currently using core library space for storage, which is not the best use of space available. For this reason they are working through what is in stack and deciding whether it should be retained or relegated to offsite storage. They do not have any off site storage, but are hoping that the university will buy into that in the near future. 
One librarian advocated the development of a national research collection retention policy, and considering Publications New Zealand access to their collections.

Libraries should consider their collections as part of a coherent national resource.

Many libraries mentioned the Council of New Zealand University Libraries (CONZUL) collaborative storage project, which they hoped would ease pressure on their shelves. CONZUL are proposing to share a collection of low-use print material and to retain one copy for the group. Duplicates would be disposed of, so the need for storage overall would reduce.

Not all respondents provided recommendations. One librarian commented that she was happy with her institution's procedures, which had been built up over trial and error. Another librarian attended a collection management seminar at the LIANZA conference last year. Talking to other people there confirmed to her that her library is doing quite well with its processes.

\section{Discussion}

In general libraries use the same sensible approaches to weeding that are advocated in the literature. For example, Dubicki (2008) suggested bringing in an expert prior to beginning a major weeding project to boost the confidence of staff in making weeding decisions. Similarly the University Librarian at one institution asked a collections manager from another library to talk to the subject librarians about weeding, as he thought that they might be more receptive to new ideas from someone outside the library.

Dubicki (2008), Handis (2007) and others stress the importance of collaboration with faculty on weeding projects. This collaboration occurs at all of the libraries surveyed, for example in the form of asking faculty to check lists of books that subject librarians want to discard. However it depends on the subject area how much collaboration is needed and as one librarian warned, it is not always useful to consult with faculty because in some cases they would just want us to keep everything.

None of the libraries use the shelf time period or a similar method as a sole criterion for weeding. One librarian did not think that Slote (1997) was helpful because academic libraries have lots of research materials that rarely circulate but are still relevant for teaching and learning. Instead libraries combine objective criteria with the judgement of colleagues and lecturers to make weeding decisions.

Collection polices and the weeding polices that complement them provide a tool to guide weeding projects (Handis, 2007). They can also deflect some of the criticism that may arise from weeding decisions (Metz and Gray, 2005). However one librarian commented that guidelines are only as good as the person using them. She relies heavily on her own judgement and that of her colleagues when deselecting. Another said that policies provide only a rough guide and allow a lot of leeway. 


\section{Conclusion}

The literature is a good source of inspiration for librarians on how to begin a weeding project. Recent articles by Handis (2007), Allen (2010) and Dubicki (2008) provide practical advice. Slote's (1997) work is rather dated now and his ideas are controversial. While the CREW formula and other approaches may be used as a guide in making weeding decisions, these guidelines should be adjusted to meet the needs of the specific library. Weeding decisions are ultimately based on the professional judgments of library staff responsible for the selection of materials (Larson, 2008). New Zealand academic libraries are doing the right things when it comes to weeding, but they are constrained by factors such as time, policy issues and the fact that weeding is a politically charged activity.

\section{Suggestions for future research}

Further research could focus on how academic libraries weed monographs from storage. The literature review uncovered no surveys on this and only two case studies on the weeding of storage facilities.

A further survey on weeding practices could cover aspects not touched on in the report, such as the effects of weeding on staff, the social-cultural implications of weeding and how academic libraries dispose of items. The survey could focus on subject specific libraries, such as law libraries. 


\section{References}

Allen, M. (2010). Weed 'em and reap: the art of weeding to avoid criticism. Library Media Connection, 28(6), 32-3. Retrieved from Library Literature \& Information Full Text database.

Arksey, H., \& Knight, P. (1999). Interviewing for social scientists: An introductory resource with examples. London: Sage.

Barclay, D. (2010). The Myth of Browsing. American Libraries, 41(6/7), 52-4. Retrieved from Library Lit \& Inf Full Text database

Burgett, S. (2006). A comprehensive weeding project for a community college library collection or bye bye books. Kentucky Libraries, 70(4), 17-21. Retrieved from Library Literature \& Information Full Text database

Banks, J. (2002). Weeding book collections in the age of the Internet. Collection Building, 21(3), 113-19. Retrieved from Library Literature \& Information Full Text database.

Bartley, M. (2000). Weeding library collections (book review). Collection Management, 24(3/4), 335-7. Retrieved from Library Literature \& Information Full Text database.

Basart, A. (1980). Criteria for weeding books in a university music library. Music Library Association Notes, 36, 819-36. Retrieved from Library Literature \& Information Science Retro database.

Bryman, A. (2008). Social research methods. ( $3^{\text {rd }}$ ed). Oxford University Press: Oxford.

Carey, C. (1992). Survival weeding. In Sellen, B-C, \& Curley, A. (Eds), The collection building reader (p.139-140). New York: Neal-Schuman Publishers.

Creswell, J. W. (2009). Research design: qualitative \& quantitative approaches. Thousand Oaks, California: Sage Publications

Crosetto, A., Kinner, L., \& Duhon, L. (2008). Assessment in a tight time frame: using readily available data to evaluate your collection. Collection Management, 33(1/2), 29-50. Retrieved from Library Literature \& Information Full Text database.

Dilevko, J., \& Gottlieb, L. (2003). Weed to achieve: a fundamental part of the public library mission? Library Collections, Acquisitions, and Technical Services, 27(1), 73-96. 
Dubicki, E. (2008). Weeding: facing the fears. Collection Building, 27(4), 132-5. Retrieved from Library Literature \& Information Full Text database.

Fabbi, J. L. (2003). Evaluating Academic Library Collections in the Age of Expedience: Weeding with a New Tool. Retrieved May 12, 2011, from http://www.mpla.us/documents/handouts/2003/fabbi.doc

Goldstein, C. (1981). Study of weeding. Bulletin of the Medical Library Association, 69, 311-16. Retrieved from Library Literature \& Information Science Retro database.

Handis, M. (2007). Practical advice for weeding in small academic libraries. Collection Building, 26(3), 84-7. Retrieved from Library Literature \& Information Full Text database.

Hann, S. (2002). Weeding of the 5000. Retrieved May 20, 2011, from http://www.coda.ac.nz/cgi/viewcontent.cgi?article=1004\&context=mit_sc_jo \&sei-redir $=1 \#$ search $=\% 22$ weeding + of + the $+5000+$ hann $\% 22$

Lancaster, F. (1988). Obsolescence, weeding, and the utilization of space. Wilson Library Bulletin, 62(9), 47-49. Retrieved from Library, Information Science \& Technology Abstracts database.

Larson, J. (2008). CREW: A Weeding Manual for Modern Libraries, Revised and Updated_. Austin, TX: Texas State Library and Archives Commission. Retrieved from http://www.tsl.state.tx.us/ld/pubs/crew/crewmethod08.pdf

Lugg, R., \& Fisher, R. (2009). Future tense - doing what's obvious: library space and the fat smoker. Against the Grain, 21(1), 75-6. Retrieved from Library Literature \& Information Full Text database.

Lugg, R., \& Fischer, R. (2008). Future tense - weeding: the time is now. Against the Grain, 20(4), 87-8. Retrieved from Library Literature \& Information Full Text database.

Mack, N., Woodsong, C., MacQueen K. M., Guest G., \& Namey E. (2005). Qualitative Research Methods: A Data Collector's Field Guide. Family Health International; Research Triangle Park, North Carolina: 2005.

Martin, M., \& Sayed, N. (2004). Good grooming: basic issues in weeding and weeding policy in library collections. Mississippi Libraries, 68(2), 36-8. Retrieved from Library Literature \& Information Full Text database.

Metz, P., \& Gray, C. (2005). Public relations and library weeding. The Journal of Academic Librarianship, 31(3), 273-9. Retrieved from Library Literature \& Information Full Text database.

Mix, V. (2010). Documents journey through time: weeding a history. Collection Building, 29(4), 131-6. Retrieved from Library Literature \& Information Full Text database. 
Narushima, Y. (2011, May 13). Students plan dust-up with uni over library's book cull. Sydney Morning Herald. Retrieved from http://www.smh.com.au

Nikkel, T., \& Belway, L. (2009). When worlds collide: dismantling the science fiction and fantasy collection at the University of New Brunswick, Saint John. Collection Management, 34(3), 194-208. Retrieved from Library Literature \& Information Full Text database.

Rogers, T. (2007). Weeding: Bringing a great practice to light. PNLA Quarterly, 71(2), 8-9. Retrieved from Library Literature \& Information Full Text database.

Shuttleworth, M. (2008). Qualitative research design. Retrieved February 15, 2011, from http://www.experiment-resources.com/qualitative-research-design.html

Slote, S. J. (1997). Weeding library collections: Library weeding methods $\left(4^{\text {th }}\right.$ ed.). Englewood, CO: Libraries Unlimited, Inc.

Williams, P., \& Halvonik, B. (2004). Collection management: Assessing and weeding the foreign language collection. College \& Undergraduate Libraries, 11(2), 103-27. Retrieved from Library Literature \& Information Full Text database. 


\section{Bibligraphy}

Bradford, J. (2005). What's coming off the shelves? A reference use study analyzing print reference sources used in a university library. Journal of Academic Librarianship, 31(6), 546-558. Retrieved from Library, Information Science \& Technology Abstracts database.

Calvert, P. \& Pope, A. (2005). Telephone survey research for library managers. Library Management 26(3), 139-151.

Collier, G. (2010). The reluctant weeder: embracing the joy of weeding. Children \& Libraries, 8(2), 51-3. Retrieved from Library Literature \& Information Full Text database.

Courtney, N., \& Jenkins, F. (1998). Reorganizing collection development and acquisitions in a medium-sized academic library. Library Acquisitions, 22(3), 287-293. Retrieved from Library, Information Science \& Technology Abstracts database.

Engeldinger, E. (1999). Weeding "naturally". College \& Undergraduate Libraries, 6(1), 46-51. Retrieved from Library, Information Science \& Technology Abstracts database.

Farber, E. (1997). Books not for college libraries. Library Journal, 122(13), 44-45. Retrieved from ABI/INFORM Global database.

Fohl, C. (2001). Weeding: an experience at Columbus State Community College. Community \& Junior College Libraries, 10(3), 47. Retrieved from Library, Information Science \& Technology Abstracts database.

Harloe, B., \& Barber, H. (1990). Managing the reference collection: the practice of pruning. Reference Librarian, (29), 159-173. Retrieved from Library, Information Science \& Technology Abstracts database.

Hendricks, D. (1975). Weeding library collections. The Journal of Academic Librarianship, 1, 25-6. Retrieved from Library Literature \& Information Science Retro database.

Holt, G. (2007). Economic realities in optimising library materials access. The Bottom Line, 20(1), 45-9.

Intner, S. (2006). Weeding, collection development and preservation. Technicalities, 26(3), 1, 14-18. Retrieved from Library Literature \& Information Full Text database.

Jenks, H. (2008). Collection development protocol: AUT University Library. Retrieved from http://www.aut.ac.nz/library/about/pq/policies/collectiondevelopment-protocol 
Mouyal, K. (2005). A balancing act: user demand versus programs driven collection management at a small, regional academic library. Collection Management, 30(4), 43-57. Retrieved from Library, Information Science \& Technology Abstracts database.

Reed, L., \& Erickson, R. (1993). Weeding: a quantitative and qualitative approach. Library Acquisitions, 17, 175-81. Retrieved from Library Literature \& Information Full Text database.

Rickman, W. (2010). Weeded: how one course became de-selected. Arkansas Libraries, 67(1), 14-16. Retrieved from Library Literature \& Information Full Text database.

Singer, C. (2008). Weeding gone wild: planning and implementing a review of the reference collection. Reference \& User Services Quarterly, 47(3), 256-64. Retrieved from Library Literature \& Information Full Text database

Tobia, R. (2002). Comprehensive weeding of an academic health sciences collections: the Briscoe Library experience. Journal of the Medical Library Association, 90(1), 94-8. Retrieved from Library Literature \& Information Full Text database.

Tooey, M. (2010). Renovated, repurposed, and still "one sweet library": a case study on loss of space from the Health Sciences and Human Services Library, University of Maryland, Baltimore. Journal of the Medical Library Association, 98(1), 40-43. Retrieved from Library, Information Science \& Technology Abstracts database.

University of Auckland Library (2010). Collection Management Plan. Retrieved from http://www.library.auckland.ac.nz/about/biblio/cdp/coldev.htm

University of Canterbury Library (2010). Collection Development Policy. Retrieved from www.canterbury.ac.nz/.../GetPolicy.aspx?file=collectiondevelopmentpolicy

University of Otago (2011). Collection Development Policy. Retrieved from http://www.library.otago.ac.nz/services/CM/CDP/index.html

University of Waikato (2010). Collection Development and Management Policy. Retrieved from http://www.waikato.ac.nz/library/files/cdp_general_info.pdf

Victoria University of Wellington (2009). Collection Development and Management Policy. Retrieved from http://www.victoria.ac.nz/architecture/pdf/5.1collection-policy.pdf

Massey University (2008). Library Collection Development Policy. Retrieved from http://www.massey.ac.nz/massey/fms/Library/Documents/Publications/cdpoli cies/Collection\%20Development\%20Policy.pdf 


\section{Appendix A}

\section{Participant Information Sheet for Library Weeding Survey}

Researcher: Angus Johnston, School of Information Management, Victoria University of Wellington

I am a student in the master of information studies at Victoria University of Wellington. As part of this degree I am undertaking a research project. This will involve examining the weeding practices of academic libraries in New Zealand, to see how they compare with best practice. I would like to find out if libraries use the recommendations from previous studies to help them weed. I would also like to find out what barriers there are to weeding. Why do libraries neglect this important part of collection management? What are the costs of not weeding?

The university requires that ethics approval be obtained for research involving human participants. This has been granted by the VUW School of Information Management's Human Ethics Committee

I will be interviewing librarians from university libraries from around New Zealand about how they weed their library's collections. Each interview will take approximately thirty minutes. If you agree to participate in this research I will call you by telephone at a time convenient to you.

The responses collected will form the basis of my research project and will be put into a written report on an anonymous basis. It will not be possible for you to be identified personally. I will be careful to edit your comments to ensure no institution is easily identifiable. All material collected will be kept confidential. No other person besides me and my supervisor, Philip Calvert, will see the data that I have collected. It will be securely held for two years after the completion of the project and then destroyed.

The research project will be submitted for marking to the School of Information Management and may be deposited in the university library's institutional repository.

Should any participants feel the need to withdraw from the project, they may do so without question at any time before June $15^{\text {th }}, 2011$.

If you have any questions about the project, please email me at johnstgeor@myvuw.ac.nz, or contact my supervisor, Philip Calvert, at the School of Information Management at Victoria University, phone 04463 6629, email: philip.calvert@vuw.ac.nz.

Signed:

Angus Johnston 


\section{Appendix B}

\section{Survey questions}

1. What are the main reasons for weeding the monographs in your library's collection?

2. What are the main factors that discourage weeding in your library?

3. Do you have storage facilities? How full are they?

4. What are the major weeding criteria that you use?

5. How regularly is weeding done in your library?

6. Does you follow written guidelines when weeding?

7. Do you refer to articles in the literature on weeding before beginning a project?

8. Which library staff members participate in the weeding process?

9. How much consultation do you have with faculty when weeding?

10. Which staff member has the final say on whether to weed an item?

11. Do you think that weeding increases circulation in your library?

12. How do you think your library's weeding procedures could be improved? 